\title{
Consumer Preference for Product Categories Sold Online and Offline
}

Nita Wanda Sari

Department of Political Science, Faculty of Social and Political Sciences, Universitas Sumatera Utara, Indonesia

\begin{tabular}{|c|c|}
\hline Article Info & ABSTRACT \\
\hline Article history: & \multirow{16}{*}{$\begin{array}{l}\text { The research purpose determines that consumers preferences for } \\
\text { online and offline shopping at different shopping experience and } \\
\text { determine products which choose consumers for online and } \\
\text { offline shopping at different shopping experience. The research } \\
\text { uses qualitative descriptive analysis obtained from the result of } \\
\text { questionnaire through interviews with the respondent based on } \\
\text { categories of some profession who have done shopping online or } \\
\text { offline in Medan City. The finding of the research shows Mean } \\
\text { Ratings of the people choose the shopping attributes such as Enjoy } \\
\text { Shopping, Shop Quickly, Large Selection and Best Price by online } \\
\text { shopping while the shopping attributes such as See-Touch } \\
\text { Handle, Personal Service, Speedy Delivery and No-hassle } \\
\text { Exchange by offline shopping. The products such as Airlines } \\
\text { Tickets, Clothes, Elektronics Products, Health and Grooming, and } \\
\text { other products (Shoes, Bags, Scarfs, Wallets, Accessories, Foods, } \\
\text { Movie Vouchers and Underwear) consumers choose by online } \\
\text { shopping. In the other hand, the people choose offline shop the } \\
\text { products such as Books, CDs, Computer Software and Sporting } \\
\text { Goods. The correlation value is o.937 for the search stages and } \\
\text { purchase stages, it means thathas the significant correlation value } \\
\text { when the consumers choose the online and offline shopping with } \\
\text { value of signification o.o1. }\end{array}$} \\
\hline Received: Feb 19, 2020 & \\
\hline Revised: Oct 24, 2020 & \\
\hline Accepted: Apr 11, 2021 & \\
\hline Keywords: & \\
\hline Consumer Preferences; & \\
\hline Product Category; & \\
\hline Online Shopping; & \\
\hline Offline Shopping. & \\
\hline & \\
\hline & \\
\hline & \\
\hline & \\
\hline & \\
\hline & \\
\hline & \\
\hline
\end{tabular}

This is an open access article under the CC BY-NC license. (c) (i) (5)

\section{Corresponding Author:}

Nita Wanda Sari,

Department of Political Science, Faculty of Social and Political Sciences,

Universitas Sumatera Utara,

Street Dr. T. Mansur No. 9, Padang Bulan Campus, Medan, 20155, North Sumatra, Indonesia

Email: nitawandasari@gmail.com

\section{INTRODUCTION}

Shopping is an activity carried out to meet needs and desires that occur repeatedly(Setiadi \& SE, 2019)(Yu \& Bastin, 2017). Besides that, shopping is also a fun activity. Nowadays, with the internet shopping can be done anytime, anywhere, while doing any activity, because there are many online shops that can be accessed via smartphones.(Wilantika, 2017)(Lestanti, 2019)(Fuentes \& Svingstedt, 2017). Online shopping has actually started to appear since the 1950s, before the internet was 
invented(Arwiedya \& Sugiarto, 2011)(Madhavaram \& Laverie, 2004). This shopping trend has been carried out by a Canadian businessman Lawrence Freiman who opened a shop front called Vis O Matic with a different concept from conventional stores, where buyers cannot buy the goods they want to pay and then take the items purchased home. However, the Vis O Matic store provides a different shopping experience. The buyer sits in a chair in front of the television screen and a sophisticated customer device can select the desired items, by flipping through and touching a button similar to today's online shop.(Lestari, 2016). After making a choice, the seller then sends the items to the house(Bariroh, 2016)(Maes et al., 1999).

The increasingly high development of internet users also encourages a great potential for the creation of online shopping(Mujiyana \& Elissa, 2013)(Marlinah, 2019)(Kharis \& Indriani, 2011)(O'cass \& Fenech, 2003). According to the China Internet Network Information Center (CNNIC), the number of internet users in China was 650 million in 2015, while in 2014 it was 648 million and is predicted to reach 656 million in 2016. (kompas.com, 2015) In addition to the increasingly high internet users, the gross trade volume at Alibaba Group Holding Limited, which announced its revenue at the online shopping festival, also reached US $\$ 17.8$ billion or equivalent to Rp.240 trillion in November 2016. As much as $82 \%$ of the gross trade volume generated came from from smartphones. Meanwhile, in 2015, the value of electronic commerce was only $69 \%$ of the total gross trade volume. (tempo.com, 2016)

Apart from China, the development of online business in Indonesia began in 1994 with the establishment of the first commercial Internet Service Provider (ISP), in 1999 Andrew Darwis established the kaskus portal which later appeared Bhinneka.com by Hendrik Tio, in 2001 the draft Law e -Commerce began to be compiled, in 2005 the Tokobagus buying and selling portal appeared, in 2007 the establishment of Doku, the first electronic payment service provider and risk management company in Indonesia, in 2011 Go-Jek, a technology company from Indonesia that serves transportation through services. ojek, in 2012 the establishment of Traveloka.com, in 2015 Tokobagus was merged with Berniaga into OLX and in 2016 the Government issued a roadmap for e-Commerce Indonesia. (liputan6.com, 2016)

In Indonesia, the development of internet users according to the Association of Indonesian Internet Service Providers (APJII) states that in 2016 there were 132.7 million Indonesians, 92.8 million people accessing them via smartphones and 82.2 million using internet services for online shopping. tempo.com, 2016) Along with the development of internet users in Indonesia, the growth of electronic commerce in Indonesia in 2015 according to Moody Analitics \& Visa, stated that the value of electronic sales transactions in Indonesia reached IDR 150 trillion, while in 2016 it is estimated to reach US \$ 20 billion or around IDR 250 trillion and it is expected that the number of transactions will continue to increase to US $\$ 130$ billion by 2020. (liputan6.com, 2016)

The city of Medan is one of the big cities in Indonesia, the people are aware of technological advances and access to the internet that is getting easier and more complete services, so online shopping will increasingly develop in the city of Medan, one of which is marked by the emergence of Shoes and Care (SAC) is one of the services The first premium shoe care in Indonesia based on social media. Shoes and Care (SAC) started a business in Yokyakarta, now it has been present in several cities, one of which is the city of Medan, prices start from IDR 25,000 to IDR 90,00o (for cleaning) and up to IDR 650,000 ( for special care). (The Jakarta Post, 2016) Apart from Shoes and Care (SAC), Lazada Indonesia recorded $60 \%$ of lazada transactions using smartphones, therefore Lazada Indonesia is trying to expand its market share by intensifying its presence in big cities outside the Indonesian capital Jakarta, such as: Yogyakarta, Medan, Bandung, Surabaya through road shows and other promotional efforts (The Jakarta Post, 2016). Shopclothes online are fun, lots of conveniences to be had. However, buying directly to the store or shopping offline, consumers can choose their own clothes better than ordering them on the website. This is because with offline shopping, they are not easily fooled by the quality of goods because consumers can directly check the clothes they want to buy, can try directly on the clothes they want to buy to see whether the size of the clothes really fits or not, can get a discount by bargaining haggling, avoiding shipping costs, being able to ask shop staff for advice on clothing products, as well as hand-to- 
hand goods. (detik.com, 2017). Apart from clothing, Canon camera sales are still more widely sold in the retail market than online sales.

Even though online buying and selling activities are increasingly popular with people in today's modern era, due to the ease of obtaining goods and services it is a special attraction, including time efficient and pocket-saving, but this is also used by irresponsible people by cheating for personal gain (Pertiwi, n.d). Such as the case of fraud under the guise of travel, where the number of victims reached hundreds of people with transactions of billions of rupiah. Deception for buying a laptop, after the money transfer it turned out that the laptop didn't come. (liputan6.com, 2016) The Ministry of Communication and Information Technology (Kemkominfo) confirmed that there are at least 43 thousand websites that are suspected of being fake online media.(Press, nd). The existence of this fake media risks endangering the legality of the media industry. Therefore, the fight against hoaxes is currently being carried out from the upstream, namely by holding outreach so that Indonesians can consume healthy content, providing complaint facilities for the public through collaboration with the community, the Ministry of Communication and Information does a white list, namely a list of websites that both formal and informal educational institutions should access. (liputan6.com, 2017)

However, apart from the crimes that occur due to increasingly sophisticated technology through online trading activities and there is also a lack of legal certainty in overcoming virtual crimes, self-awareness is needed to be more thorough and careful before using the internet as an activity to purchase goods or services, by visiting official sites, authorized and trusted sellers by checking whether there are misspellings or missing punctuation marks to avoid counterfeit goods, also investigating the site's reputation by investigating the company's reputation via google so as not to experience crimes committed by irresponsible parties.(Suhanda, 2018)(Kie, 2018)

The development of online shopping is indeed increasingly promising, there are many benefits that can be felt by consumers by shopping online(Al-Debei et al., 2015)(Demangeot \& Broderick, 2007)(Casaló et al., 2007). Online shopping provides benefits for consumers including: price offers and discounts are much more attractive than those offered in offline shopping, online shopping can be done anywhere even when busy, without the need to take the time to go shopping outside the house so that it can add variable costs such as costs transportation, parking fees and other costs(Ong Ardhe Saliem, 2020). In addition, online shopping also provides a wide selection of products with unique variations of models and is usually difficult to find when shopping offline.(Sudarso et al., 2020)(Ahn et al., 2004)(Chiang \& Dholakia, 2003). However, for certain products consumers prefer to shop offline because of the desire to touch and examine the product directly so as not to become a victim of crime via the internet(Redmiles et al., 2019).

\section{RESEARCH METHOD}

The research used is descriptive qualitative. Descriptive research is a method of researching a group of people, an object, a condition, a system of thought or a class of events in the present by conducting interviews.(Rukajat, 2018). The purpose of this research is to make systematic, factual, and accurate descriptions, descriptions or paintings of the factors, properties and relationships between the phenomena being investigated. The focus of this research is on consumer preferences which are seen from the factors that are thought to influence consumers in the use of online and offline shopping services. The consumers in this study are several consumers in the city of Medan. The product categories that have been determined are product categories such as airplane tickets, clothing, books, CDs, computer software, electronic products, health and care products, sports equipment and other products that appear after conducting research. In this study do not use population, because this research comes from certain cases that exist in social situations and because there is no official institution that releases data or amounts regarding online shopping and offline shopping. In this study, the term population does not use, but it is called a "social situation" which consists of three elements, namely: place, actors, and activity that interact synergistically.(Rerung, 2018). Sampling using purposive sampling technique, namely the technique of sampling data sources based on certain considerations. This sampling 
technique is taken based on the sample or subject that contains the most certain characteristics, traits, or characters in the population.(Onwuegbuzie \& Collins, 2017)(Serra et al., 2018). So, in this study the sample is consumers who can use smartphones, use internet access and have even made purchases online or offline. The sample of this research was taken from the type of work according to the 2015 Indonesian Standard Business Field Classification (KBLI) because these consumers already contain certain characteristics, traits, or characters needed in research such as already having regular income or having income from sources. other sources and being able to use a smartphone and be able to access the internet, in order to be able to shop online and shop offline to meet their needs. The analysis technique used in this research is descriptive statistics(Fisher \& Marshall, 2009)(Mishra et al., 2019)(Marshall \& Jonker, 2010)(Kock, 2011). Descriptive statistics, namely describing consumer preferences for product categories sold online and offline. Descriptive statistics to see consumer trends in choosing online and offline services in shopping based on different products and based on different shopping attributes (Park \& Kim, 2003).

\subsection{Analysis technique with Arithmetic Mean}

The arithmetic mean or simply the average is often called a set of quantitative data which is the sum of all the data divided by the number of existing data. Mathematically, the average is:

Information:

$$
\overline{\boldsymbol{X}}=\frac{\left(\sum_{i=1}^{n} \mathbf{x i}\right)}{\mathbf{n}}
$$

$$
\begin{array}{ll}
\bar{x} & =\text { calculated average, } \\
\sum \mathrm{xi} & =\text { from the sum of each data from } \mathrm{x} 1 \text { to } \mathrm{xn} \\
\mathrm{n} & =\text { amount of data }
\end{array}
$$

\subsection{Validity and Reliability Test}

a. Validation Test

Validity or validity aims to measure the accuracy of a measuring instrument to perform its measuring function. The technique used for the validity test is the Spearman Rho correlation. The measurement instrument is said to have high validity, if the tool performs a measurement function in accordance with the purpose of the measurement. Statistically, the correlation number obtained must be compared with the critical number of the correlation table $r$ value for a significance level of 0.05 (at the 95\% confidence level) and a significance level of 0.01 (at the $99 \%$ confidence level). This study measures whether the mean values in the search and purchase stage instruments are related to consumer tendencies in determining online and offline services for different product categories, whether they have high validity,

b. Test Reliability

Reliability is a test conducted to determine the extent to which measuring instruments can provide consistent results when used repeatedly. The technique used to assess reliability is Cronbach alpha. An instrument is said to be reliable or reliable, if the alpha is more than o.6o. This study measures whether the mean values in the search and purchase stage instruments against consumer tendencies in determining online and offline services for different product categories produce reliable or reliable numbers when compared to an alpha of o.6o.

\section{RESULTS AND DISCUSSIONS}

\subsection{Characteristics of Respondents}

The characteristics of the respondents analyzed in this study include gender, age, education, occupation and income. The characteristics of these respondents can be explained as follows:

a. Gender

Gender is a factor that can influence individuals in choosing shopping services both online and offline based on different product categories and based on different shopping attributes, this is related to the level of importance of each gender. 
Table 1. Classification of Respondents based on Gender.

\begin{tabular}{ccc}
\hline Gender & amount & Percentage (\%) \\
\hline Man & 18 & 45 \\
Women & 22 & 55 \\
amount & 40 & 100 \\
\hline
\end{tabular}

Source: Primary data processed, 2017

Based on Table 1, it is known that $45 \%$ ( 18 people) of respondents were male and $55 \%$ ( 22 people) of respondents were female. This shows that the consumers in the selection of product categories that are sold online and offline are dominated by women rather than men. It can be concluded that the trend of consumers in online shopping and offline shopping can be done by anyone because as we know that shopping is something that is always associated with a woman, but now shopping is also favored by men because shopping nowadays can be done easily.

b. Age

Age is a factor that can determine consumers in choosing online and offline services, because the knowledge, views, experiences and abilities of individuals in using smartphones and age considered adults so that they are allowed to access the internet will affect consumer preferences for products sold online and offline.

Table 2. Classification of Respondents by Age

\begin{tabular}{lll}
\hline Age & amount & Percentage \\
\hline $20-30$ years & 27 & 67.5 \\
$31-40$ years & 9 & 22.5 \\
$41-50$ years & 3 & 7.5 \\
$>51$ years & 1 & 2.5 \\
Total & 40 & 100 \\
\hline
\end{tabular}

Source: Primary data processed, 2017

Based on table 2, it shows that the consumers who live in Medan City are between 20-30 years old, namely $67.5 \%$ ( 27 people). Meanwhile, other age distribution, namely the age between 31 40 years is $22.5 \%$ ( 9 people), consumers aged $41-50$ years are $7.5 \%$ ( 3 people) and consumers aged $>50$ years are $2.5 \%$ ( 1 person). The majority of consumers are adults (productive), which is between 20 and 30 years.

c. Level of education

A person's education level reflects a rational thinking pattern. The higher the level of education of a person, the wider the person's knowledge will be, so that the decision to choose shopping online and offline to meet their needs in consuming goods and services will be even higher. This is because the level of education is an important factor in shopping online and offline. It is hoped that consumers can be more careful in choosing shopping services.

Table 3. Classification of Respondents based on Education

\begin{tabular}{lcc}
\hline \multicolumn{1}{c}{ Level of education } & amount & Percentage (\%) \\
\hline SD & o & o \\
Junior High & 0 & 0 \\
High school & 6 & 15 \\
Academy & 4 & 10 \\
Bachelor & 30 & 75 \\
Others & 0 & 0 \\
Total & 40 & 100 \\
\hline
\end{tabular}

Source: Primary data processed, 2017

Based on Table 3, it can be seen that the majority of respondents' education level is undergraduate program, which is $75.0 \%$ (30 people). Meanwhile, the distribution of other education levels is academy, which is $10.0 \%$ (4 people), and SMA (15.0\%) (6 people). This shows 
that the higher the level of education, the higher the consumers who do online shopping and offline shopping, this is because the level of education is very influential, a consumer has knowledge of the accuracy and accuracy of using a smartphone and accessing the internet.

d. Profession

Employment is a factor that determines the tendency of consumers to choose shopping services. This is because consumers who are going to do shopping both online and offline are already working to receive income, so that consumers can make purchases that meet their needs.

Table 4. Characteristics of Respondents by Type of Work

\begin{tabular}{lcc}
\hline Profession & amount & Percentage (\%) \\
\hline Government employees & 7 & 17.5 \\
Private employees & 4 & 10 \\
entrepreneur & 5 & 12.5 \\
Lecturer & 5 & 12.5 \\
Teacher & 9 & 22.5 \\
Bank employees & 3 & $7 \cdot 5$ \\
Education clerks & 4 & 10 \\
Freelance & 2 & 5 \\
Midwife & 1 & 2 \\
Total & 40 & 100 \\
\hline
\end{tabular}

Source: Primary data processed, 2017

Table 4 shows that most of the respondents in this study worked as teachers, namely $22.5 \%$ (9 people), $17.5 \%$ civil servants ( 7 people), $12.5 \%$ self-employed and lecturers ( 5 people), private employees and educational staff at $12.5 \%$ (5 people). 10.0\% (4 people), bank employees $7.5 \%$ (3 people), freelancers $5.0 \%$ ( 2 people) and midwives $2.5 \%$ ( 1 person). These results indicate that the majority are teachers. This is because this group of respondents already has income and these consumers have a high level of activity, so they require various conveniences including shopping quickly, efficiently and with a wide range to support all their activities.

e. Income

Income is the most important factor, this is because a consumer can purchase goods and services if the consumer has regular income or has revenue from other sources in order to be able to shop online or offline.

Table 5. Characteristics of Respondents by Income

\begin{tabular}{ccc}
\hline Income & amount & Percentage \\
\hline 2,000,000 - 3,000,000 & 25 & 62.5 \\
3,000,001 - 4,000,000 & 15 & 37.5 \\
$>$ 4,000,000 & 0 & 0 \\
Total & 40 & 100 \\
\hline
\end{tabular}

Source: Primary data processed, 2017

Table 5 shows that respondents with an income of IDR 2,00o,000 - IDR 3,000,000 are 62.5\% (25 people), and respondents with an income of IDR 3,000,001 - IDR 4,000,000 are 37.5\% (15 people), this shows that that consumers with low incomes do the most shopping online and offline compared to consumers with high incomes.

\subsection{Arithmetic Mean Analysis}

Before conducting an arithmetic mean assessment to see the tendency of consumers to choose shopping services based on different shopping attributes and different product categories, the results of interviews using a questionnaire have been predetermined that the respondents in choosing online and offline shopping services, namely using a scale of 1-10. Where a scale of $1-5$ it is determined that the respondent chooses offline shopping both to make purchases of goods and services and also chooses offline shopping based on different shopping attributes, while a scale of 6 - 10 determines that the 
respondent chooses online shopping is good for doing purchase of goods and services and choose online shopping based on different shopping attributes. Measurements used with a Likert scale, where respondents state the level of agree or disagree, and have or never in measuring how often consumers shop online or offline, it can be stated in various statements about behavior, objects, people or events. In determining consumer preference criteria for product categories sold online and offline, it can be done at the following intervals:

The lowest preference score is: 1

The highest preference score is: 10

Interval $\frac{10-1}{10}=0.9$

For consumer preferences based on shopping stages, such as search, comparison to purchase decisions in offline shopping, the measurements used are as follows in table 7.

Table 7 Criteria for Consumer Preference for Product Categories Sold Online and Offline Based on Shopping Attributes

\begin{tabular}{llll}
\hline & Offline & & Online \\
\hline Average & Criteria & Average & Criteria \\
\hline $1.00-1.90$ & Strongly disagree & $5.51-6.40$ & Strongly disagree \\
$1.91-2.80$ & Disagree & $6.41-7.30$ & Disagree \\
$2.81-3.70$ & Don't agree & $7.31-8.20$ & Don't agree \\
$3.71-4.60$ & Agree & $8.21-9.10$ & Agree \\
$4.61-5.50$ & Strongly agree & $9.11-10.00$ & Strongly agree \\
\hline
\end{tabular}

a. Consumer Preference by Stage of Shopping for Different Products Sold Online and Offline.

To find out the causes of consumer tendencies in choosing shopping services both online and offline, we need to look at the stages of shopping carried out by consumers before choosing a shopping service to use for shopping. The search stage is the stage where consumers before shopping online and offline use the internet as a medium or directly, to search for products or services to be purchased. This search can be about product and service information such as quality, brand, usability and others. The comparison stage is the stage where consumers make comparisons of products or services via the internet as a medium or directly, such as regarding prices, brands, quality, specifications and uses. The purchasing stage is the stage where consumers make purchases of products or services online or offline. Based on the shopping stages for the search, comparison and purchase stages, consumer preferences are obtained in choosing online shopping services and offline shopping. The results of the average count of 40 respondents indicate consumer preferences that of the 40 respondents for products such as: Airplane tickets, books, CDs, clothes, computer software, electronic products, health and care products, sporting goods and other products being sold online and offline by shopping stage for search, comparison and purchase stages. This can be seen from the intensity of consumers in purchasing these products online and offline. Based on the results of interviews through a questionnaire for the shopping stage: Based on the shopping stages for the search, comparison and purchase stages, consumer preferences are obtained in choosing online shopping services and offline shopping. The results of the average count of 40 respondents indicate consumer preferences that of the 40 respondents for products such as: Airplane tickets, books, CDs, clothes, computer software, electronic products, health and care products, sporting goods and other products being sold online and offline by shopping stage for search, comparison and purchase stages. This can be seen from the intensity of consumers in purchasing these products online and offline. Based on the results of interviews through a questionnaire for the shopping 
stage: Based on the shopping stages for the search, comparison and purchase stages, consumer preferences are obtained in choosing online shopping services and offline shopping. The results of the average count of 40 respondents indicate consumer preferences that of the 40 respondents for products such as: Airplane tickets, books, CDs, clothes, computer software, electronic products, health and care products, sporting goods and other products being sold online and offline by shopping stage for search, comparison and purchase stages. This can be seen from the intensity of consumers in purchasing these products online and offline. Based on the results of interviews through a questionnaire for the shopping stage: comparisons and purchases are obtained by consumer preferences in choosing online shopping services and offline shopping. The results of the average count of 40 respondents indicate consumer preferences that of the 40 respondents for products such as: Airplane tickets, books, CDs, clothes, computer software, electronic products, health and care products, sporting goods and other products being sold online and offline by shopping stage for search, comparison and purchase stages. This can be seen from the intensity of consumers in purchasing these products online and offline. Based on the results of interviews through a questionnaire for the shopping stage: comparisons and purchases are obtained by consumer preferences in choosing online shopping services and offline shopping. The results of the average count of 40 respondents indicate consumer preferences that of the 40 respondents for products such as: Airplane tickets, books, CDs, clothes, computer software, electronic products, health and care products, sporting goods and other products being sold online and offline by shopping stage for search, comparison and purchase stages. This can be seen from the intensity of consumers in purchasing these products online and offline. Based on the results of interviews through a questionnaire for the shopping stage: The results of the average count of 40 respondents indicate consumer preferences that of the 40 respondents for products such as: Airplane tickets, books, CDs, clothes, computer software, electronic products, health and care products, sporting goods and other products being sold online and offline by shopping stage for search, comparison and purchase stages. This can be seen from the intensity of consumers in purchasing these products online and offline. Based on the results of interviews through a questionnaire for the shopping stage: The results of the average count of 40 respondents indicate consumer preferences that of the 40 respondents for products such as: Airplane tickets, books, CDs, clothes, computer software, electronic products, health and care products, sporting goods and other products being sold online and offline by shopping stage for search, comparison and purchase stages. This can be seen from the intensity of consumers in purchasing these products online and offline. Based on the results of interviews through a questionnaire for the shopping stage: This can be seen from the intensity of consumers in purchasing these products online and offline. Based on the results of interviews through a questionnaire for the shopping stage: This can be seen from the intensity of consumers in purchasing these products online and offline. Based on the results of interviews through a questionnaire for the shopping stage:

(a). For airplane tickets, the average obtained is $8.8 \mathrm{o}$ for the search, comparison stage and an average of 8.70 for the purchase stage, this shows that consumers search and compare online, because consumers find it easier and faster to get information about products, both quality and price. In the flight ticket purchase stage, this shows that consumers have purchased $>4$ times in the last 1 year online, namely by using Traveloka, Tiket.com and Pegi-pegi. (b) Books, the average obtained for the search stage is 7.67 , the comparison is 6.10 this shows that consumers search and compare online, because consumers find it easier and faster to get information about products, both quality and price, but for the purchase stage an average of 4.95 is obtained, this shows that for the purchasing stage consumers choose offline services, in a period of more than 5 years through Gramedia or other bookstores, although there are some consumers who buy books and comics online through Jasakom and Gramedia Online. (c). CD, the average obtained for the search and purchase stage is 1.57 consumers making purchases offline. (d). Clothes, the 
average obtained is $8.7 \mathrm{o}$ for the search stage, a comparison of 8.60 and a purchase of 8.62 . This shows that consumers do online searches and comparisons, because consumers find it easier and faster to get information about products, both quality and price or discounts. Stage of purchasing clothes consumers buy> 4 times in the last 1 year online, namely by using Lazada, Sale stock, Zalora and Shopee. (e). Computer Software, the average obtained for the search, comparison and purchase stages is 1.30. This shows that consumers make purchases offline or even never buy computer software at all. (f). Electronic Products, the average obtained is 8.20 for the search stage, a comparison of 7.15, this shows that consumers do online searches and comparisons, because consumers find it easier and faster to get information about products, both quality and price. Purchase stage of 6.62, this shows consumers choose online services, buy 1 time within the last 1 year to purchase electronic products online, namely by using Lazada, Tokopedia, Buka lapak and Bli.bli. (g). Health and care products, the average obtained is 7.07 for the search stage, the comparison stage is 6.65 . This shows that consumers do online searches and comparisons, because consumers find it easier and faster to get information about products, both quality and price. The Purchase Stage is $6.8 \mathrm{o}$, this shows that consumers choose online services on average 1 (one) time in the last 1 year to make online purchases, namely by using Lazada, Bukalapak and privately owned online shops that are already known by consumers. (h). Sports Equipment, the average obtained is 4.57 for the search stage, while the comparison and purchase stages were 4.65. This shows that consumers choose offline services for the shopping stage from search, comparison and purchase in $>4$ times in the last 1 year through Stores that sell sporting goods and some on Lazada. (i). For other products, the average obtained in the search stage is 8.20 , the comparison is 7.90 and the purchase is 8.40 . It should be explained that other products here are products that appear to be purchased online such as: Shoes, Bags, Hijabs, Accessories, Wallets, Watch vouchers, comics, Food and Underwear. These products consumers choose online services with purchases $>4$ times within the last 1 year through Lazada, Shoppee, Zalora, women country, Medan deals,

\section{b. Consumer Preference Based on Shopping Attributes for Different Products}

a) Enjoyment of Shopping

Consumer preferences based on one of the shopping attributes, namely the enjoyment of shopping for products such as airplane tickets, obtained an average of 8.80 , meaning that consumers agree to enjoy online shopping, clothes are obtained on average of 6.30, meaning that consumers agree to enjoy shopping, electronic products are obtained on average of 5.85 , meaning that consumers are very On average, they did not agree to enjoy shopping online, health and care products obtained an average of 7.82, meaning that consumers did not agree with enjoying online shopping, and other products obtained an average of 7.27 , meaning that consumers did not agree with enjoying online shopping. Consumers find it easier and more relaxed because only a smartphone connected to the internet can shop. Meanwhile, books are obtained an average of 6.30, meaning that consumers agree to enjoy offline shopping.

b) Shopping Speed

Consumers find it faster and easier because only a smartphone connected to the internet can shop. Meanwhile, products such as CDs obtained an average of 2.20, computer software obtained an average of 1.40 and sports equipment obtained an average of 5.50, meaning that consumers choose offline shopping activities, consumers feel buying CDs and computer software only when they need them, so consumers are more better buy it offline.

c) Many choices

This means that consumers do not agree with more product choices with online shopping and other products obtained an average of 8.70 , meaning that consumers agree with more product choices by shopping online. Consumers choose online shopping activities. Consumers feel they have more choices because there are usually categories to sub- 
categories, more variety of models, more unique and even rare ones can't be found when buying offline. Meanwhile, products such as CDs obtained an average of 1.80 , computer software obtained an average of $\mathbf{2 . 4 0}$ means that consumers choose offline shopping activities, consumers feel buying CDs and computer software only when they need them so consumers are better off buying them offline and feel the choice of CDs and Computer Software is readily available offline.

d) Best Price

30 means that consumers agree on lower prices by shopping online. Consumers feel the price offered is cheaper than buying offline, which usually requires bargaining. In addition, online shopping can get promo or discount prices as well as consumers can get gifts for free. Meanwhile, products such as CDs obtained an average of 3.50, computer software obtained an average of 3.70 , meaning that consumers choose offline shopping activities, consumers feel that they buy CDs and computer software only when they need them, so consumers are better off buying them offline. in online shopping you can get promo or discount prices as well as consumers can get gifts for free. Meanwhile, products such as CDs obtained an average of 3.50, computer software obtained an average of 3.70, meaning that consumers choose offline shopping activities, consumers feel that they buy CDs and computer software only when they need them, so consumers are better off buying them offline. in online shopping you can get promo or discount prices as well as consumers can get gifts for free. Meanwhile, products such as CDs obtained an average of 3.50, computer software obtained an average of 3.70, meaning that consumers choose offline shopping activities, consumers feel that they buy CDs and computer software only when they need them, so consumers are better off buying them offline.

e) See, Touch and Check

Some consumers feel that even though these products actually require inspection, when consumers feel confident about buying online, consumers prefer to shop online to repurchase these products and because of the availability of Cash On Delivery (COD) payment methods, consumers increasingly trust them. Meanwhile, products such as CDs obtained an average of 1.42 , computer software obtained an average of 1.90 means that consumers choose offline shopping activities, consumers feel buying CDs and computer software only when they need them so consumers are better off buying them offline and feel they can evaluate the product by touching, checking and offline viewing of CD and Computer Software products.

f) Personal Service

85 means that consumers do not agree to choose online shopping activities. Some consumers feel that personal service is sufficient in purchasing these products online, this is also driven by consumers who already feel confident in online shopping. Meanwhile, products such as CDs obtained an average of 4.0 and computer software obtained an average of 4.22, which means that consumers agree to choose offline shopping activities, consumers feel that they buy CDs and computer software only when they need them so consumers are better off buying them offline and feel more comfortable. better service regarding CDs and Computer Software when buying offline. It is also driven by consumers who already believe in online shopping. Meanwhile, products such as CDs obtained an average of 4.0 and computer software obtained an average of 4.22 , meaning that consumers agree to choose offline shopping activities, consumers feel buying CDs and computer software only when they need them so consumers are better off buying them offline and feel more getting better service regarding CDs and Computer Software when buying offline. It is also driven by consumers who already believe in online shopping. Meanwhile, products such as CDs obtained an average of 4.0 and computer software obtained an average of 4.22 , meaning that consumers agree to choose offline shopping activities, consumers feel buying CDs and computer software only when they need them so consumers are better off buying them 
offline and feel more getting better service regarding CDs and Computer Software when buying offline.

g) Delivery Speed

97 means that consumers do not agree to choose online shopping activities. Consumers feel that delivery speed is not a problem for purchasing airplane tickets because it is only less than 3 minutes, but for product categories that have been determined, consumers agree that by shopping offline the products can be directly handled and brought home. Meanwhile, products such as CDs obtained an average of 1.80 and computer software obtained an average of 2.40 means that consumers choose offline shopping activities, consumers feel buying CDs and computer software only when they need them so consumers are better off buying them offline and $\mathrm{CD}$ and Computer Software products can be immediately handled when buying offline. However, for product categories that have been determined, consumers agree that by shopping offline the products can be directly handled and brought home. Meanwhile, products such as CDs obtained an average of 1.80 and computer software obtained an average of 2.40 means that consumers choose offline shopping activities, consumers feel buying CDs and computer software only when they need them so consumers are better off buying them offline and $\mathrm{CD}$ and Computer Software products can be immediately handled when buying offline. However, for product categories that have been determined, consumers agree that by shopping offline the products can be directly handled and brought home. Meanwhile, products such as $C D$ s obtained an average of 1.80 and computer software obtained an average of 2.40 means that consumers choose offline shopping activities, consumers feel buying CDs and computer software only when they need them so consumers are better off buying them offline and $\mathrm{CD}$ and Computer Software products can be immediately handled when buying offline.

h) No Return and Swapping Complications

The complexity of returns and exchanges means that consumers can return goods without hassle, error-free and exchange easily without adding any costs. In this case when consumers shop online and shop offline, they hope that it is not complicated to return products and exchange products when they are not suitable. with the desires of consumers. Consumer preferences based on one of the shopping attributes, namely the complexity of returning and exchanging products such as airplane tickets, an average of 8.80 means that consumers agree to shop online, clothes are obtained on average of 8.42, meaning that consumers agree to shop online, electronic products are obtained on average 8.52 means that consumers agree to shopping online, and other products are obtained by an average of 8.42 , which means that consumers are equal to shopping online, For this attribute, consumers feel that there is no hassle in returning and exchanging because consumers when shopping online want to cancel a purchase can immediately refund or there are provisions to cancel the transaction. health and care products obtained by an average of 8.05 means that consumers do not agree with online shopping, sports equipment is obtained an average of 6.87 means that consumers do not agree to choose online shopping activities. Meanwhile, products such as CDs obtained an average of 1.80 , computer software obtained an average of 2.40 means that consumers choose offline shopping activities, consumers feel buying CDs and computer software only when they need them so consumers are better off buying them offline and CD and Software products Computers can be put in hand when buying offline.

\subsection{Validity and Reliability Test}

\section{a. Validity test}

The validity test aims to determine the accuracy and accuracy of the measuring instrument in carrying out the function of the measuring instrument. Given that the questionnaire in the form of a Likert scale produces ordinal data, the validity test is carried out using the Spearman Rank correlation statistical approach (Spearman Rho). Rank Spearman aims to see the level of 
strength or closeness of the relationship between variables and to see whether the relationship is significant or not. Statistically, the correlation value obtained must be compared with the critical figures of the r-value correlation table to determine the significance level of 0.05 ( $95 \%$ confidence level) and o.o1 (confidence level of 99\%) with the number of respondents as many as 40 people.

Correlations

\begin{tabular}{|c|c|c|c|c|}
\hline & & & Pencarian & Pembelian \\
\hline \multirow[t]{2}{*}{ Spearman's rho } & Pencarian & $\begin{array}{l}\text { Correlation Coefficient } \\
\text { Sig. (2-tailed) } \\
\text { N }\end{array}$ & $\begin{array}{r}1.000 \\
. \\
9\end{array}$ & $\begin{array}{r}.937^{* *} \\
.000 \\
9\end{array}$ \\
\hline & Pembelian & $\begin{array}{l}\text { Correlation Coefficient } \\
\text { Sig. (2-tailed) } \\
\text { N }\end{array}$ & $\begin{array}{r}.937^{*} \\
.000 \\
9\end{array}$ & 1.000 \\
\hline
\end{tabular}

**. Correlation is significant at the 0.01 level (2-tailed).

Based on the Spearman Rank correlation analysis that has been carried out for the mean value at the search and purchase stages, a correlation value of 0.937 shows that there is a very strong relationship / correlation for the search and purchase stages of products sold online and offline shopping and based on the significance value or Sig obtained $0.000<0.01$, meaning that there is a significant relationship for the search and purchase stages of products sold online and offline at a $99 \%$ confidence level.

b. Reliability Test

Reliability test aims to determine the extent to which measuring instruments can provide consistent results and stability. The technique used to assess reliability is Cronbach's alpha, an instrument is said to be reliable if (reliable) if the alpha value is more than o.6o.

Reliability Statistics

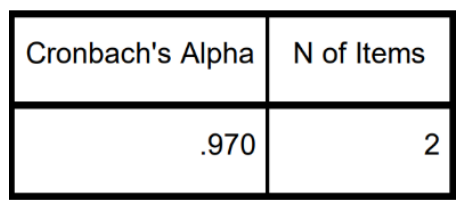

Based on the reliability test using the Cronbach's alpha technique, it was obtained a value of $0.970>0.60$, meaning that the mean instrument from the search and purchase stage was reliable or reliable.

\section{CONCLUSION}

Consumer preferences based on shopping attributes can be seen from consumer reasons, (a). Enjoy shopping when consumers can do shopping activities easily, comfortably and casually, anywhere, anytime and while doing anything, consumers can shop. (b). Shopping speed is also faster with a smartphone connected to the internet, so consumers can shop quickly without taking time to go out and have to get around. (c). Many choices, consumers prefer shopping online because online stores have more choices because they usually consist of categories to sub-categories, there are also more variations of models, and the products offered are more unique. (d). The price is cheaper, Compared to the prices offered in offline shopping, the prices offered by online stores are usually cheaper with better quality 
(e). Seeing, touching and checking, consumers prefer offline shopping because to see, touch and check products in person can only be done in offline shopping. (f). Personal service, consumers choose the best service when shopping offline because consumers can directly meet face to face and ask questions about the product completely and clearly, although some consumers choose online services because some products purchased through online stores have provisions on how to pay Cash On Delivery (COD ) or payments that can be made when the product arrives and consumers can see, touch and inspect the product directly for damage or defects. However more consumers prefer offline services that are the best to attribute shopping to see, touch and inspect. (g). The speed of shopping, consumers prefer shopping offline because the products purchased can be directly handled and brought home. (h). There is no hassle of returns and exchanges, consumers prefer offline shopping because consumers and sellers can determine and ensure directly that products can be returned or exchanged, although some consumers who choose online services because online stores also have conditions that consumers can cancel their purchases, namely by refund. But consumers prefer that online services are the best in the no-hassle attributes of returns and exchanges. 2. Based on the shopping stages, to purchase products such as: airplane tickets, clothing, electronic products, health and care products, and other products (shoes, bags, headscarves, accessories, wallets, watch vouchers, comics, food and underwear), consumers prefer online shopping, while products for books, CDs, computer software and sporting goods consumers prefer offline shopping. With a correlation value of 0.937 , it means that the mean values have a very strong relationship at the search and purchase stages, and a value of 0.970 is obtained which means that it is reliable or reliable with a significance level of 0.01 or at a $99 \%$ confidence level. Wallets, watch vouchers, comics, food and underwear), consumers prefer online shopping, while products for books, CDs, computer software and sports equipment consumers prefer offline shopping. With a correlation value of 0.937 , it means that the mean values have a very strong relationship at the search and purchase stages, and a value of 0.970 is obtained which means that it is reliable or reliable with a significance level of 0.01 or at a $99 \%$ confidence level. Wallets, watch vouchers, comics, food and underwear), consumers prefer online shopping, while products for books, CDs, computer software and sports equipment consumers prefer offline shopping. With a correlation value of 0.937 , it means that the mean values have a very strong relationship at the search and purchase stages, and a value of 0.970 is obtained which means that it is reliable or reliable with a significance level of 0.01 or at a $99 \%$ confidence level.

\section{REFERENCES}

Ahn, T., Ryu, S., \& Han, I. (2004). The impact of the online and offline features on the user acceptance of Internet shopping malls. Electronic Commerce Research and Applications, 3(4), 405-420.

Al-Debei, M. M., Akroush, M. N., \& Ashouri, M. I. (2015). Consumer attitudes towards online shopping: the effects of trust, perceived benefits, and perceived web quality. Internet Research.

Arwiedya, M. R., \& Sugiarto, S. (2011). Analisis Pengaruh Harga, Jenis Media Promosi, Resiko Kinerja, dan Keragaman Produk Terhadap Keputusan Pembelian Via Internet Pada Toko Online (Studi Kasus Pada Konsumen Toko Fashion Online yang bertindak sebagai Reseller yang ada di Indonesia). Universitas Diponegoro.

Bariroh, M. (2016). Transaksi Jual beli dropshipping dalam perspektif fiqh muamalah. Jurnal Ahkam, 4(2).

Casaló, L., Flavián, C., \& Guinalíu, M. (2007). The impact of participation in virtual brand communities on consumer trust and loyalty: The case of free software. Online Information Review.

Chiang, K.-P., \& Dholakia, R. R. (2003). Factors driving consumer intention to shop online: an empirical investigation. Journal of Consumer Psychology, 13(1-2), 177-183.

Demangeot, C., \& Broderick, A. J. (2007). Conceptualising consumer behaviour in online shopping environments. International Journal of Retail \& Distribution Management.

Fisher, M. J., \& Marshall, A. P. (2009). Understanding descriptive statistics. Australian Critical Care, 22(2), 93-97.

Fuentes, C., \& Svingstedt, A. (2017). Mobile phones and the practice of shopping: A study of how young adults use smartphones to shop. Journal of Retailing and Consumer Services, 38, 137-146.

Kharis, I. F., \& Indriani, F. (2011). Studi Mengenai Impulse Buying dalam Penjualan Online (Studi Kasus di Lingkungan Universitas Diponegoro Semarang). Universitas Diponegoro.

Kie, J. (2018). Analisis faktor-faktor yang mempengaruhi keputusan konsumen dalam pembelian secara online dengan kepercayaan sebagai variabel moderating (studi di kota pematangsiantar). 
Kock, N. (2011). Using WarpPLS in e-collaboration studies: Descriptive statistics, settings, and key analysis results. International Journal of E-Collaboration (IJeC), 7(2), 1-18.

Lestanti, Y. (2019). Transaksi Layanan Koin Game Goyang Shopee Pada Jual Beli Online dalam Perspektif Hukum Islam. Jurnal Al-Hakim: Jurnal Ilmiah Mahasiswa, Studi Syariah, Hukum Dan Filantropi, 1(2), 249-262.

Lestari, D. (2016). Supernova 1: Kesatria, Putri dan Bintang Jatuh (Vol. 1). Bentang Pustaka.

Madhavaram, S. R., \& Laverie, D. A. (2004). Exploring impulse purchasing on the internet. ACR North American Advances.

Maes, P., Guttman, R. H., \& Moukas, A. G. (1999). Agents that buy and sell. Communications of the ACM, 42(3), 81ff.

Marlinah, L. (2019). Mendorong Pertumbuhan Ekonomi Indonesia Melalui Penguatan Sektor Ekonomi Digitalpreneur dan Creativepreneur. Ikra-Ith Ekonomika, 2(1), 32-38.

Marshall, G., \& Jonker, L. (2010). An introduction to descriptive statistics: A review and practical guide. Radiography, 16(4), e1-e7.

Mishra, P., Pandey, C. M., Singh, U., Gupta, A., Sahu, C., \& Keshri, A. (2019). Descriptive statistics and normality tests for statistical data. Annals of Cardiac Anaesthesia, 22(1), 67.

Mujiyana, M., \& Elissa, I. (2013). Analisis faktor-faktor yang mempengaruhi keputusan pembelian via internet pada toko online. J@ TI Undip: Jurnal Teknik Industri, 8(3), 143-152.

O'cass, A., \& Fenech, T. (2003). Web retailing adoption: exploring the nature of internet users Web retailing behaviour. Journal of Retailing and Consumer Services, 10(2), 81-94.

Ong Ardhe Saliem, S. A. L. (2020). Analisis Pengaruh Promosi Melalui Digital Marketing Dan Labelisasi Halal Produk Terhadap Keputusan Pembelian Dalam Perspektif Ekonomi Islam. UIN Raden Intan Lampung.

Onwuegbuzie, A. J., \& Collins, K. M. T. (2017). The role of sampling in mixed methods-research. KZfSS Kölner Zeitschrift Für Soziologie Und Sozialpsychologie, 69(2), 133-156.

Park, C., \& Kim, Y. (2003). Identifying key factors affecting consumer purchase behavior in an online shopping context. International Journal of Retail E Distribution Management.

Pers, J. D. (n.d.). Era Media Online, New Media.

Pertiwi, I. Y. (n.d.). Upaya Perlindungan Konsumen oleh Asean Committee Consumer Protection (ACCP) dalam Perdagangan Era Digital di Asia Tenggara.

Redmiles, E. M., Bodford, J., \& Blackwell, L. (2019). "I just want to feel safe”: A Diary Study of Safety Perceptions on Social Media. Proceedings of the International AAAI Conference on Web and Social Media, 13, 405-416.

Rerung, R. R. (2018). E-Commerce, Menciptakan Daya Saing Melalui Teknologi Informasi. Deepublish.

Rukajat, A. (2018). Pendekatan penelitian kuantitatif: quantitative research approach. Deepublish.

Serra, M., Psarra, S., \& O’Brien, J. (2018). Social and physical characterization of urban contexts: Techniques and methods for quantification, classification and purposive sampling. Urban Planning, 3(1), 58-74.

Setiadi, N. J., \& SE, M. M. (2019). Perilaku Konsumen: Perspektif Kontemporer pada Motif, Tujuan, dan Keinginan Konsumen Edisi Ketiga (Vol. 3). Prenada Media.

Sudarso, A., Purba, B., Ardiana, D. P. Y., Manullang, S. O., Karim, A., Purba, P. B., Muliana, M., Siagian, V., Siregar, M. N. H., \& Jamaludin, J. (2020). Konsep E-Bisnis. Yayasan Kita Menulis.

Suhanda, I. A. (2018). Perlindungan Konsumen Dalam Perjanjian Jual Beli Online Dengan Sistem Rekening Bersama (Studi Transaksi Jual Beli Online Melalui www. tokopedia. com).

Wilantika, C. F. (2017). Pengaruh penggunaan smartphone terhadap kesehatan dan perilaku remaja. Jurnal Obstretika Scientia, 3(2).

Yu, C., \& Bastin, M. (2017). Hedonic shopping value and impulse buying behavior in transitional economies: A symbiosis in the Mainland China marketplace. In Advances in Chinese Brand Management (pp. 316-330). Springer. 